\title{
Non Exceptional Exceptions: The Latest on The United State of America and Mexico Supreme Courts' Hague Abduction Decisions (Lozano and Direct Amparo under Revision 903/2014)
}

\author{
Nuria GONZÁLEZ MARTÍN*
}

\begin{abstract}
Nowadays there is an increase of international families, that is, those formed by individuals under different countries' jurisdictions. International families are not exempt from suffering a crisis, hence the increase in cross border family conflicts. This way, in cases where there are minors and a couple's relationship is terminated, we face the regrettable increase of international child abductions by one of the parents. This paper analyses the r980 Hague Convention on Civil Aspects of International Child Abduction and provides an analysis of two recent cases brought to the American and Mexican Supreme Courts. Finally, we outline the need to cooperate between different authorities to accomplish and expedite solution in the best interest of the child.
\end{abstract}

Keywords: international child abduction - international family mediation - 1980 Hague Convention

\section{INTRODUCTION}

The Hague Convention of 25 October 1980 on the Civil Aspects of International Child Abduction (hereafter The 1980 Hague Convention) ${ }^{\mathrm{I}}$ establishes procedures to secure the prompt return of children -under sixteen- to the State of their habitual residence in cases of wrongful removal or retention ${ }^{2}$ by one of their parents. ${ }^{3}$ When we are in the presence of those cases, we are talking about international parental child abduction. ${ }^{4}$

$\mathrm{PhD}$ in Private International Law, Pablo de Olavide University, Seville, Spain. Senior Researcher, Law Research Institute, National Autonomous University of Mexico (UNAM). Visiting Scholar and Fellow, Stanford Law School 20122015. External counselor to Mexico's Foreign Affairs Ministry on Private International Law. Family, Civil and Commerce law mediator, certified by Mexico City's Supreme Court. Editor in Chief, "Boletín Mexicano de Derecho Comparado".

I Under abduction section. Currently there are 94 Contracting States to this Convention, that is, we are talking about a successful Convention. The 1980 Hague Convention was created under The Hague Conference on Private International Law, an universal organism that create private international conventions or treaties. The 1980 Hague Convention with an important cooperation content. Most current Conventions under the Hague Conference on Private International Law entail specific forms of cooperation. Cooperation means several thinks, for us, the most important meaning is to be confidence between the Central Authorities, between the States, text available at <http://www.hcch.net>, accessed 5 April 2015.

The 1980 Hague Convention (Hard Law) is actually specialized in the subject -international parental child abductionbut has some important missing links that prevents ir from being well and actually applied in practice. Those shortcomings could be overcome through the Guide of Good Practice on Mediation arising from The Hague Conference on Private International Law (Soft Law). See, in this subject, S. Vigers, 7 Mediating International Child Abduction Cases. The Hague Convention, (Hart Publishing, UK, 201I) at I3. See also, N. González Martín "International Parental Child Abduction and Mediation: An Overview", 48-2 Family Law Quarterly, Summer 2014, at 319-350.

2 The 1980 Hague Convention, Art. 3, "The removal or the retention of a child is to be considered wrongful where: a) it is in breach of rights of custody attributed to a person, an institution or any other body, either jointly or alone, under the law of the State in which the child was habitually resident immediately before the removal or retention; and b) at the time of removal or retention those rights were actually exercised, either jointly or alone, or would have been so exercised but for the removal or retention." The rights of custody mentioned in sub-paragraph a) above, may arise in particular by operation of law or by reason of a judicial or administrative decision, or by reason of an agreement having legal effect under the law of 
The 1980 Hague Convention has a clear rule, the prompt return, that is, the immediately restitution in order to protect the children in their best interest, 5 providing only limited exceptions for the children's non-return. ${ }^{6}$ Therefore, we have a rule or norm and "exceptional" exceptions.

I. Rule. To locate and restitute the child immediately to his/her habitual state of residence and to restore the status quo prior to the abduction as quickly as possible to lessen the harmful effects of the wrongful removal or retention for the child, in his/her best interest;

2. Exception. No restitution:

- Art. I2(2): the exceptions to returning the child are the child becoming settled due to the passing of time (one year since the wrongful removal or retention);

- Art. I3(I)(a) consent or acquiescence by the applicant;

- Art. $\mathrm{I3}(\mathrm{I})(\mathrm{b})$ a grave risk that return will expose the child to harm or place him in a intolerable situation;

- $\operatorname{Art~13(2)~the~objection~by~a~mature~child;~and~}$

- Art. 20 the violation of fundamental human rights.

With this in mind, it seems that the principles are clear and well defined but the problem is when an exception to the summary return mechanism is established, the courts of the place where the child is

that State", text available at <http://www.hcch.net/index_en.php?act=conventions.text\&cid=24>, accessed I6 April 2015 .

3 Or closed parenthood like grandparents, uncles or even tutor or guardian. We talk about the left-behind parent and the taking parent. The term "left-behind parent" or "searching parent" refers to the parent who claims that his/her custody rights were breached by a wrongful removal or retention. The term "taking parent", "kidnapping parent" or "parental kidnapper" refers to the parent who is alleged to have wrongfully removed a child from his/her place of habitual residence to another State or to have wrongfully retained a child in another State.

4 An extensive work we can see it in N. Gonzalez Martin, "International Parental Child Abduction and Mediation", I5 Anuario Mexicano de Derecho Internacional, (2015), text available at $<$ http://biblio.juridicas.unam.mx/revista/DerechoInternacional/>, accessed I May 20I5. Although this paper is not focused in the mediation subject we believe that this Alternative Dispute Resolution has an incredible potential to resolve these kind of cases, for this reason, we would like to refer some articles that contribute to obtain more information about it. In this sense, see M. A. Kucinski, "Creating a Successful Structure to Mediate International Parental Child Abduction Cases", 26 American Journal of Family Law (20I2); M. A. Kucinski, "Culture in International Parental Kidnapping Mediation", 9 Pepperdine Dispute Resolution Law Journal, University School of Law (2009), among others, and N. Gonzalez Martin, "Mediation in Cases of International Child Abduction by one of the Parents and Voluntary Cross-Border Agreements in International Child Abduction Disputes: Mexican Case", I4I Boletín Mexicano de Derecho Comparado (2014) at 867-908, text available at <http://biblio.juridicas.unam.mx/revista/DerechoComparado/> accessed I5 May 20I5. Likewise, it is important to introduce, together to the Alternative Dispute Resolution as mediation, the Online Dispute Resolution with all his capacity. See N. Gonzalez Martin, Nuria and M.M. Albornoz, "Feasibility Analysis of Online Dispute Resolution in Developing Countries", 44 The University of Miami Inter-American Law Review, (2013), available at $<$ http://www.academia.edu/2234730/Feasibility_Analysis_of_Online_Dispute_Resolution_in_Developing_Countries $>$, acessed 4 June 20I5; and M.A. Kucinski and C. Rule, "Online Dispute Resolution and Cross-Border Family Disputes", BNA Family Law Reporter (2015), passim.

5 Art. 3.I United Nations Convention on The Rights of the Child (UNCRC) express "In all actions concerning children [...] the best interest of the child shall be a primary consideration", text available at $<$ http://www.ohchr.org/english/law/crc.htm>, accessed 9 March 2015.

6 The 1980 Hague Convention express those exceptions in articles $\mathrm{I2}(2) ; \mathrm{I} 3$ and 20. 
present after the abduction that is, the courts where the child is generally have a discretion as to whether to return the child to the State of the child's habitual residence. ${ }^{7}$

Currently, it seems like the exceptions are the rule and the rule is the exception which constitutes a lack of respect for the Convention's articles, a lack of respect for the spirit of the Convention ${ }^{8}$ and worse, an indescribable danger for the children involved in this kind of parental conflict, with an emotional and (sometimes even) physical damage for the rest of their lives.

\section{ARTICLE I2 (2) OF THE I980 HAGUE CONVENTION EXCEPTIONS TO RETURN ORDERS: LOZANO VS. MONTOYA ALVAREZ ${ }^{9}$}

\section{(I) Preliminary note}

When one parent abducts a child, in the terms described above, and flees to another country, the other parent may file a petition in that country for the return of the child pursuant to The 1980 Hague Convention. If the parent files a petition within one year of the child's removal or retention, a court "shall order the return of the child forthwith", ${ }^{\text {,o }}$ but when the petition is filed after the one year period expires, the court "shall... order the return of the child, unless it is demonstrated that the child is now settled in its new environment". ${ }^{\text {II }}$

\section{(2) Background}

On March 5, 2014, the Supreme Court of the United States published its third statement, since 2010 on an international parental child abduction case. ${ }^{12}$ We refer to the matter as Lozano vs. Montoya Alvarez, where the issue of refusal to return was based on article I2 (2). The one-year period could not be extended by equitable tolling due to the taking parent's concealment of the child. Article I2 explicitly provides for the period to commence on "the date of the wrongful removal or retention" and makes no provision for an extension.

The decision was no restitution for the child based in the best interest of the child that is now settled and expressing that article I2's one year period is not subject to equitable tolling. Judge

R. Schuz, The Hague Child Abduction Convention; A Critical Analysis, (Hart, Oxford, 20I3) at II; P. Beaumont; K. Trimmings "Child Abduction: Recent Jurisprudence of the European Court of Human Rights", 64 International and Comparative Law Quarterly, (2015) at 39.

8 E. Pérez Vera, Explanatory Report, Convention on the Civil Aspects of International Child Abduction, Hague Conference on Private International Law, III Actes et Documents de la Quartorzieme Session 426 (1980) at 458, text available at $<$ www.hcch.net/upload/expl28s.pdf>, accessed 9 March 2015.

9 Lozano v. Alvarez Montoya, I34 S.Ct. I224 (2014).

ro Supreme Court of the United States (SCUS). Syllabus. M. J. Lozano v. D. L. Montoya Alvarez Certiorari to the United States Court of Appeals for the Second Circuit. October Term (2013) at I.

II Ibid.

I2 There are two previous decisions: Abbott v. Abbott, 560 U.S. I, (2010), the court considered whether a ne exeat clause, a clause prohibition one parent from removing a child from the country without the other parent's consent, was a 'right of custody' that invoked the remedies under the Hague Convention; and Chafin v. Chafin, I33 S.Ct. IOI7 (20I2), the court considered whether a petition for return is mooted by the return of the child to his or her habitual residence. 
Thomas delivered the opinion for a unanimous Court and Judges Alito, Breyer and Sotomayor filed a concurring opinion.

\section{(3) The facts ${ }^{13}$}

Manuel Jose Lozano and Diana Lucia Montoya Alvarez are the parents of a girl born in October 2005, a girl that is the center of this dispute. Lozano and Montoya Alvarez resided with their daughter in London, United Kingdom, until November 2008, when Montoya Alvarez left with the child for a women's shelter. In July 2009, Montoya Alvarez and the child left the United Kingdom and ultimately settled in New York. Lozano did not locate Montoya Alvarez and the child until November 20Io, sixteen months after the child was wrongfully removed from her habitual residence. Lozano filed a Petition for Return of Child pursuant to The 1980 Hague Convention in the Southern District of New York. Finding that the petition was filed more than one year after removal, the court denied the petition on the basis that the child was now settled in New York.

The point here is that Lozano asked to extend the one year period by equitable tolling because the taking parent, that is, Montoya Alvarez, concealed the child's location. ${ }^{14}$

\section{(4) Comments}

The Supreme Court of the United States considered, on one hand, that there was no general presumption that equitable tolling applies to treaties, even if The 1980 Hague Convention were subject to a presumption that statutes of limitations may be tolled; article I2's one-year period is not a statute of limitations. ${ }^{\text {I5 }}$

On the other hand, the Convention drafters did not choose to delay the period's commencement until discovery of the child's location; "equitable tolling is therefore neither required by the Convention nor the only available means to advance its objectives". ${ }^{16}$ As well, the Supreme Court based its decisions on those made by national tribunals of other signing states ${ }^{17}$ to identify common

I3 (SCUS) M. J. Lozano v. D. L. Montoya Alvarez. On Writ Certiorari to the United States Court of Appeals for the Second Circuit. No. 12-820 (2014).

${ }^{14}$ See about this L. D. Wardle, "Is the Now Settled Defense to a Hague Convention Claim for Return of a Child Subject to Equitable Tolling- Lozano v. Alvarez”, Preview U.S. Sup. Ct. Case. I39 (2013-2014) at 4.

Is See K. Robinson, "Left-Behind Parent is Out of Luck if Child Taken by Parent is Hidden", The Bureau of National Affairs, Snapshot, The United States Law Week, March II (2014) at I; S. B. Ruben, "New Urgency over Abductions", California Lawyer, (2014) at 34; M. Coyle "Court Sides With Abducting Parent on Child's Return", Supreme Court Brief (Online), (2014) at 2; K. Daugirdas, and J. Davis Mortenson, "U.S. Supreme Court Interprets Child Abduction Treaty", Io8 Am. J. Int'l L., (2014) at 559; N. Fontaine, "Don't Stop the Clock: Why Equitable Tolling Should not be Read into The Hague Convention on International Child Abduction”, 54 Boston College Law Review, (2013) at 209I-2I26.

${ }_{16}$ (SCUS) M. J. Lozano v. D. L. Montoya Alvarez. On Writ Certiorari to the United States Court of Appeals for the Second Circuit. No. 12-820. (2014) at 13-15.

${ }_{17}$ "[...] many intermediate courts in contracting states -including England, Canada and Hong Kong -have explicitly refused to apply the principle in Hague Convention cases. Moreover, the court said that even if the presumption in favor of equitable tolling had force outside of domestic law, it would not apply here because the I-year period in Art. I2 is not a statue of limitations". Robinson, Kimberly, "Left-Behind Parent is Out of Luck if Child Taken by Parent is Hidden”, The Bureau of National Affairs, Snapshot, The United States Law Week, (20I4), at 2; A. L. Estin, "The Hague Abduction Convention and The United States Supreme Court", 48 Family Law Quarterly, (2014) at 25I. 
interpretation principles, likewise, the opinion of those tribunals was taken into consideration in cases where they assert their discretion when ordering the restitution after the one year period has lapsed.

Thus, the government of the United States of America, through its State Department, has played a significant role in these cases ${ }^{18}$ by presenting an Amicus Brief, initially at the Appeals Court and then at the Supreme Court, declaring that (i) equitable tolling did not apply in a one year period due to article (I2); and (ii) the court retained equitable discretion to order the restitution of a child at any moment, and this can be done even if the child were adapted or settled. ${ }^{9}$

According to Silberman, the United States Supreme Court, in all three cases it has had to resolve since 2010, contributed to establishing an international jurisprudence for The I980 Hague Convention $^{20}$, i.e., it looks for a uniform and autonomous interpretation of the convention, since it has to be interpreted in multiple national courts with systems and juridical cultures that differ from each other, although this pursuit can be rarely found in other latitudes or juridical systems, as it happens in the case we presented regarding Mexico. Silberman expressed that in order to accomplish such goals, that is, for national courts to achieve a global jurisprudence in the operation and interpretation of The 1980 Hague Convention, one can resort to a number of mechanisms incorporated by the US Supreme Court through Abbot, Chafin and Lozano. Thus, the Supreme Court: "(I) embraces principles of treaty interpretation, with an emphasis on object and purpose, ${ }^{2 \mathrm{I}}(2)$ focused on the structure of the Convention itself and identified certain autonomous concepts in the Convention, (3) looked to the travaux préparatoires and Explanatory Report on the Convention, (4) referenced decisions and rulings of other courts, and (5) recognized the role of the Hague Conference on Private International Law to aid in interpreting the Convention". ${ }^{22}$

Definitely, putting into practice, and thereby, correct and updated application of international family situations entails a true and accurate knowledge of international norms, both Hard Law and Soft $\mathrm{Law}^{23}$, that can only materialize through the specialization of all interlocutors involved in a

I8 L. J. Silberman, "The United States Supreme Court's Hague Abduction Decisions (Abbott, Chafin, Lozano): Developing a Global Jurisprudence", New York University School of Law, Working Paper, (2014). See too Sumitomo Shoji America, Inc. v. Avagliano, 457 EE.UU. 176, 184, n. Io (1982).

19 See Silberman, "The United States..., supra n. I8, at 28.

${ }_{20}$ Ibid., at I, 4, 2I; A. L. Estin, "Families Across Borders: The Hay Children's Conventions and the Case for International Family Law in the United States", 62 Fla. L. Rev. (2010) at 47.

${ }_{21}$ Principles for the interpretation of international agreements are set for in American Law Institute, Restatement os the Law (Third), The Foreign Relations Law of the United States \&325 (1988) Cit for L. J. Silberman, "The United States..., supra n. I8, at 4 .

22 Ibid.

23 In previous pages, as footnotes, we have referred to the complementary role that law making techniques such as Hard Law and Soft Law entail. On this occasion, we clarify some aspects related to it. Thus, in Private International Law we can distinguish two forms of law making: Hard Law represented by the traditional binding international instruments such as international treaties or conventions and Soft Law represented by non binding international instruments such as Model Laws and Guides of Best Practices for instance, which allow us to update and to put into practice many of the Hard Law instruments, which, due to their rigid nature, cannot be reformed or updated through their own articles. N. González Martín, "Actualidad del derecho internacional privado en materia familiar y niñez: Hard Law y Soft Law”, Obra jurídica Enciclopédica en Homenaje al Centenario de la Escuela Libre de Derecho, (Porrúa, México, 20I2), passim. 
process of this nature, providing the required follow up and consequently delivering adequate results for the population we intend to protect.

\section{ARTICLE I3 (B) OF THE I98O HAGUE CONVENTION EXCEPTIONS TO RETURN ORDERS: DIRECT AMPARO UNDER REVISION 903/20I4}

\section{(I) Preliminary note}

As we mention, when one parent abducts a child and flees to another country, the other parent may file a petition in that country for the return of the child pursuant to the 1980 Hague Convention. If the parent files a petition base in Article I3(I)(b) "a grave risk that return will expose the child to harm or place him in a intolerable situation", the taking parent must prove this circumstances and the court must have a "discretion" in order to find the best interest of the child.

\section{(2) Background}

The Supreme Court of Justice of the Nation in Mexico (Suprema Corte de Justicia de la Nacion, SCJN), has approximately twenty cases in which it has issued a decision regarding the international child abduction by one of the parents but it was only a couple of years ago that the Supreme Court actually began to do some hermeneutic work. Definitely, Mexico's interpretation of the courts is recent and to get unanimous conformity criteria for a good interpretation of The 1980 Hague Convention takes time because it not only has to decide in observance of the articles of the International Convention but also of its spirit, found as well in the explanatory reports by special commissions that keep updates regarding its practical application, among others.

The decision, in this Direct Amparo under Revision 903/2014 was no restitution for the child based in article I3 (b) "a grave risk that return will expose the child to harm or place him in a intolerable situation". The Mexican Supreme Court Judges delivered the opinion for a unanimous vote and Judges Cossio and Zaldivar filed a concurring opinion.

The vote of the majority - the unanimous opinion- admitted that The 1980 Hague Convention's basic idea was violated, which is to resolve procedures regarding International Child Abduction expeditiously, by requesting the restitution on November 16, 20II, and until the date of the resolution of Direct Amparo in the revision made on July 2, 20I4, a final decision was not available. It was also alleged that the procedure was not compliant with the transverse principle of safeguarding the best interest of the child, reversing the judgment, by majority vote, and returning the case to the Appeals Court, to resolve the litigation, following the guidelines set by the sentence.

\section{(3) The facts ${ }^{24}$}

A couple married in November 2007 are parents of two children born in Spain in 2008 y 20I0, the children are in the center of this dispute. The parents resided with their children in the Balear Islands,

\footnotetext{
${ }^{24}$ In this Mexican case identity sensitive data was omitted.
} 
Spain, until September $201 \mathrm{r}$ when the mother, with their children, left Spain and settled in Mexico. The father, the left-behind parent, filed a Petition for Return of Child pursuant to The r980 Hague Convention in Mexico in November 2orI, that is, two months and half after the wrongful removal. ${ }^{25}$

An important number of appeals was filed and the result is that in July 2014 the Mexican Supreme Court returned the case to the corresponding court, that is, the issue is pending for decision after almost three years, with allegations based on domestic violence (art I3 (I)(b)) and the child settled due to the passing of time-as a "second" allegation- ${ }^{26}$

\section{(4) Comments}

Analyzing the arguments exhibited by the SCJN, the majority vote is based on four premises: ${ }^{27}$

- The topic regarding that filing a return request "is not enough to proceed to the return" can be quickly dismissed when we consider that we are talking about a convention that was created, or that emerged from cooperation among authorities both administrative and judicial from different countries, where, immediate location and return of the child to his habitual residence prior to wrongful removal or retention are considered from the perspective of child protection, so that all matters concerning his rights are resolved in the child's best interest. We find it unacceptable that in this decision the rule concerning the immediate return of the subtracted minor or minors is disregarded. As a proof of this we can see that in a recent decision issued in 2015 the SCJN itself, expressed through Judge Zaldivar, ${ }^{28}$ that what is most beneficial for the minor is his immediate return to his country of origin.

- Regarding the usage of allegations or exceptions, in the particular case of the grave risk implied by domestic violence, these conditions must be adequately proved by the part presenting the allegations, to avoid abuse of such exceptions attempting to avoid a return. We must promote a more restrictive application of the causes for denial of return. ${ }^{29}$ According with the particular vote

25 Direct Amparo under revision: 903/2014, passim.

26 P. Beaumont, et al., "Child Abduction: Recent Jurisprudence of the European Court of Human Rights", 64 International and Comparative Law Quarterly (2015) at 48 and ss.

27 An extended version can be seen in N. Gonzalez Martin, "Sustracción internacional parental de menores y mediación. Dos casos para la reflexión: México (Amparo Directo en Revisión 903/2014) y los Estados Unidos de América (Lozano v Montoya Alvarez", 29 Revista Electronica de Estudios Internacionales (2014), text available at <www.reei.org>, accessed 30 June 2015 .

28 Direct Amparo under revision 4465/2014 issued on January 14, 2015. Judge Arturo Zaldivar Lelo de Larrea. Statement $\mathrm{OO}_{3} / 2015$, Mexico City January 14 2015, text electronically available at <https://www.scjn.gob.mx/saladeprensa/Paginas/cs_comunicacion.aspx.>, accessed I March 2015. The "Primera Sala" of the SCJN issued a sentence, under the Thesis of Judge Arturo Zaldivar, in which he established that, in general, what is most beneficial for a minor who has been wrongfully removed by one of the parents and taken into another country, is for him to be immediately returned to his country of origin, unless one of the extraordinary causes foreseen by the Hague Convention on child abduction is verified." Obviously when he speaks about the exception of extraordinary causes, or exception allegations, he does so requesting that they be used with the due caution.

29 LEPCA Report, A questionnaire and the first European Conference on Cross Border Family Issues, held from the 7th May 20I4, the Peace Palace, The Hague, the Netherlands, 20I4, text available at <http://www.lepca.eu/en/news.htm>, accessed 5 February 2015. From the data obtained in LEPCA " $61 \%$ of the respondents stated that in $50 \%$ of their cases the court ordered that return of the child. The grounds of refusal were in more than $50 \%$ on the basis of the 'grave risk for the well-being of the child and the fact that the child was not settled in its new environment" (at p. 7), last access on February 5 , 2015 . 
of Judge Cossio there is no evidence of domestic violence, " the burden of the evidence cannot be so lax as to permit that an allegation by itself, without any other elements, validates an illicit act that violated the custody rights both of the father and the minors", in fact, the Collegiate Court did consider all the elements, concluding that the evidence provided was insufficient to uphold the claims. $^{30}$

- To invoke the voice of the child according to his age and maturity, or to be listened through a representative, does not imply that it has to be considered per se, that is, the mere declarations of a minor in one sense of the other, or in this case, what is expressed by those who represent them, does not become the decision of the competent authority. ${ }^{3 \mathrm{I}} \mathrm{We}$ coincide with Judge Cossio when he expressed "the participation of the minors does not imply the automatic and mechanical admission by a judge of the child's wishes, especially when an exception was argued based on article $\mathrm{I} 3(\mathrm{~b})$ of the Convention" ${ }^{2}$

- Finally, regarding the integration of the minors to their new location after one year has elapsed as established by the Convention itself in article $\mathrm{I} 2$, its very purpose is defeated when a clear delay tactic can be used when this exception is invoked, which is equally a delicate matter because the return of minors is denied supposedly in their best interest. This hypothesis is not present in the particular case commented, since the international request for return of the minors was filed two months after the removal, so the aforementioned dilation implied by the allegations ${ }^{33}$ should not jeopardize the return of the minors; again, in words of Judge Cossio this situation "generates an extremely pernicious effect", which is to validate an illegal act by the mere passage of time, in clear violation of the custody rights of both the father and the children. It seems that it suffices to unlawfully remove minors long enough, so as not have to abide by the law "34.

As a corollary, we can say that the decision being commented, can be interpreted as showing that the argument of adaptation or settled and the year lapsed generates an erroneous interpretation and application of The 1980 Hague Convention of 1980; however, and in this context, as we mentioned, we have to finalize the review of the Mexican case with a happy coincidence: the admission by the First Chamber of the Supreme Court of Justice of the Nation, of another case for review, the Direct

30 Particular vote of Judge Cossio, in which he expresses that this can be noticed on pages 80-91 of the sentence appealed.

${ }^{3}$ Another topic that is clearly interesting, is the Recommendation and Conclusion of the Sixth Meeting of the Special Committee on the practical operation of the 1980 Hague Convention, where it is mentioned that Judges should be trained how to listen - to know how to listen- to the minor directly. See Gonzalez Martin, Nuria, "Relatoria de la Sexta reunion de la Comisión Especial sobre el funcionamiento práctico del Convenio de La Haya de 1980 sobre los Aspectos Civiles de la Sustracción Internacional de Menores y del Convenio de La Haya de 1996 relativo a la competencia, ley aplicable, reconocimiento, ejecución y cooperación en materia de responsabilidad parental y de medidas de protección de los niños, La Haya, Holanda, I-Io junio 20II", I2 Anuario Mexicano de Derecho Internacional (2012).

32 Particular Vote of Judge Cossio, at II (our translation).

33 Within the European Union, the European Committee has encouraged the Hague Special Committee to introduce limits to the causes for appeals. The 1980 Hague Convention requires agile procedures to avoid delays in the return of the child. LEPCA, Report, supra p.7, latest access or consultation on February 5, 2015.

34 Direct Amparo under revision 903/20I4. Particular vote Judge Cossio, at I2 (our translation). 
Amparo under Revision 4465/2014 issued on January I4, 201535, with a more than encouraging result, as detailed in the statement of the Supreme Court: "In cases of international child abduction by a parent, it is best for the child to be restored immediately to his country of origin: First Chamber " 36. Thus, we bring up some more paragraphs that denote the Mexican Supreme Court's willingness to make progress when confronted with responses that were inconsistent with the rule invoked.

\section{CONCLUSIONS}

I. The 1980 Hague Convention requires close cooperation between the courts and other authorities of the two countries (article 7) and one way to promote the safety and security of the child is to act expeditiously to protect the child from confusion and from the necessity to adapt to the conditions created by an abduction, that is, return "forthwith", as specified in Article I2, should be the norm.

2. On the other hand, of course, The 1980 Hague Convention carefully provides escape clauses in article I3 (b)- for situations where return would expose the child to grave risk of physical or psychological harm or otherwise place her or him in a intolerable situation, but what happens when these provisions can be used when there isn't a grave risk, normally domestic violence? Is there a use and abuse of this exceptions? Is there "discretion" by the courts, by the judges of the place where the child is present after the abduction?

3. Why do we always forget the child's right to maintain regular personal relations and direct contact with both parents, guaranteed by article I0.2 UNCRC, ${ }^{37}$ directly connected with the aforementioned interests of the child?

4. Another equally outstanding matter is the principle stating the minor's right to be listened to in all cases with a general character and without exceptions, (article I2 UNCRC) ${ }^{38}$ but the main principle does not mean that the opinion of the child has to taken into consideration per se, i. e, the mere statement one way or another of a child, or in this case, the statements of those who represent him, do not constitute the basis for the decision of the competent authority ${ }^{39}$, and it has also been expressed by the Judge Cossio through his dissent when stating that "the participation of children does not imply automatic and mechanical admission by the judge of the child's wishes" 40

5. Likewise, in this decision the exception in the aforementioned article $\mathrm{I2}$ (2) is alleged, that is, the exceptions to returning the child are the child becoming settled due to the passing of time -one year since the wrongful removal or retention-, but this assumption does not apply in the case discussed,

\footnotetext{
35 Direct Amparo under revision 4465/2014. Ministro Ponente Arturo Zaldivar Lelo de Larrea and Secretario Javier Mijangos y González. Acuerdo de la Primera Sala de la Suprema Corte de Justicia de la Nación of January I4th, 2015.

${ }_{36}$ Comunicado $\mathrm{OO}_{3} / 2015$, México D.F. January $4^{\text {th }} 2015$, text available at <https://www.scjn.gob.mx/saladeprensa/Paginas/cs_comunicacion.aspx>, accessed 5 March 2015. (our translation)

37 United Nations Convention of 20 November 1989 on the Rights of the Child, Art. Io (2), available at $<$ http://www.ohchr.org/english/law/crc.htm>, accessed 5 March 2015.

${ }_{38}$ F. J. Forcada, "Capítulo Décimo Tercero, Derecho del Niño a Ser Oído" en L Tenorio (coords.) La Restitución Internacional de la Niñez. Enfoque Iberoamericano, Doctrinario y Jurisprudencial, (Porrúa, México, 20II) at 246-265.

39 R. C. Pérez Manrique, "El interés superior del niño en el convenio de La Haya de 1980. Orientaciones para su interpretación”, 56 Revista de Derecho de Familia (2012), at 23 y ss 23 y ss.

$4^{\circ}$ Particular Vote Judge Cossio, at II.
} 
since the demand for return of the children was presented after just two months of the abduction in the Mexican case; hence, the delays caused by the various appeals in the process, should not endanger the return of children; in words of Judge Cossio, this situation "generates an extremely pernicious effect" ${ }^{\text {"4 }}$.

Definitely, these encouraging sentences and the mindset expressed by the court are helpful to illustrate what the right interpretation and application of the law is. Along with this important idea regarding the application and correct practical implementation of a matter as complex and delicate as international parental child abduction, emphasis should be placed on the subject we attempt to protect. Thus, we are talking about how to place at the center of the debate the parents' obligation to bear in mind at every moment, that their children are really fragile and that their main responsibility is to prevent them from suffering any kind of damage and, on the other hand, once the conflict has reached the court, how to manage the court's discretion in the best interest of the child: two very different, yet closely connected matters.

On the other hand, we must also highlight that education is at the base of the society's structure and to educate is to give people the possibility to obtain information about certain conducts and certain consequences. We have, as part of this society, to put our knowledge at the service of the people that are in a family situation like international parental child abduction; to cooperate with a unique goal: pursue the best environment for the children, a healthy atmosphere in every sense, in order to raise adults who are emotionally and physically whole. As parents, as professionals (lawyers, mediators, psychologists, social workers, therapeutics, judges, etcetera) we have a project in common to safeguard the integrity of our children.

Another matter that has been emphasized along the present text is that of "discretion" and the caution we must exercise when an exception is alleged and assumed. The word "discretion" should be subject to human rights review since we have several cases where the judges have clearly failed to justify whether the exceptions were correctly applied. The exception's allegations, by the parents, and the "discretion", by the courts, may imply great harm to an individual child by allowing the enforcement of The 1980 Hague Convention decision to be delayed and pending in a very lengthy process in the courts; often several years.

It would seem as though - as expressed by Mexican judge Cossio in his particular vote - "an illegal action (that is, the abduction) could be validated by the mere fact of time lapsing, in clear violation of the custody rights of the parent as well as those of the minors. It would seem as though it suffices to abduct the minors illegally long enough so as not to have to abide by the law", ${ }^{42}$ a matter that goes hand in hand with the fundamental matter illustrated in the Lozano case with the concealment of the daughter.

The 1980 Hague Convention promotes simplified procedures but the reality is another because we need an intense and unconditional cooperation between all the interlocutors that are working in this

4I Ibid, at $\mathrm{I} 2$.

42 Direct Amparo under revision: 903/2014. Particular vote Judge Cossio, at I2 and I3 (our translation). 
subject, which is the main content of The 1980 Hague Convention. To cooperate is to trust, especially when it comes to discussing about and working with children. 